\title{
VICARIOUS LIABILITY IN THE CONFLICT OF LAWS-TOWARD A THEORY OF ENTERPRISE LIABILITY UNDER "FORESEEABLE AND INSURABLE LAWS": III*
}

\section{ALBERT A, EHRENZWEIG $\dagger$}

IN a number of recent articles I have tried to show that the "place of hatm" formula of tort conflicts law, propagated in the Restatement, is partly incorrect and partly in need of a new rationalization. More specifically, I have tried to show that in all tort conflicts law the lex fori should be restored to its historical function as the basic rule; $;^{1}$ that other laws will come into play primarily, and perhaps only, in those exceptional situations where either party has been forced into a forum with an unfavorable law by the prevailing law of jurisdiction; and that the primary auxiliary laws in such cases are on the one hand the law of the place of conduct for admonitory tort liabilities," and on the other hand laws reasonably "foreseeable and insurable" for tort liabilities which primarily serve to distribute the losses caused by modern mechanical "enterprise." In the two earlier Articles of this series I have developed this latter theme with regard to the liability of motorists to their guest passengers, ${ }^{3}$ and the liability of suppliers to their ultimate consumers. ${ }^{4}$ The present Article will offer a similar analysis for another important type of "enterprise liability," that loosely called vicarious liability. Within this field, perhaps the most important liability in the present-day law of conflict of laws is the statutory liability of the owner of an automobile for injuries caused by the negligence of its operator. ${ }^{6}$ This liability will therefore be the

*The last in a series of three articles. The first two appear in the present volume at pages 595 and 794 respectively.

†Walter Perry Johnson Professor of Law, University of California (Berkeley).

1. See Ehrenzweig, The Lex Fori-The Basic Rule in the Conflict of Lauus, 58 Micu. L. REv. 637 (1960) ; Ehrenzweig, Lex Fori-Exception or Rule?, 32 Rocky Mr. L. REv. 13 (1959). See also Currie, On the Displacement of the Laze of the Fortum, 58 CoLuM. L. Rev. 964 (1958); Kelso, The Process of Analyzing Choice-of-Laze Problems, 1959 WAsu. U.L.Q. 37, 51-63; Kramer, Interests and Policy Clashes in Conflict of Lauts, 13 RuTcess L. REv. 523 (1959) ; Traynor, ls This Conflict Really Necessary?, 37 TexAs L. Rev. 657, 668-75 (1959).

2. See Ehrenzweig, The Place of Acting in Intentional Multistate Torts, 36 Mins. L. Rev. 1 (1951); Ehrenzweig, Alienation of Affections in the Conflict of Laws (article to be published in the Cornell Law Quarterly for Spring 1960).

3. Ehrenzweig, Guest Statutes in the Conflict of Lawes-Toward a Theory of Eusrprise Liability Under "Foreseeable and Insurable Laws": I, 69 Y ALE L.J. 595 (1960).

4. Ehrenzweig, Products Liability in the Conflict of Laws-Toward a Theory of Enterprise Liability Under "Foreseeable and Insurable Laws": II, 69 Y ALE L.J. 794 (1060). See also Ehrenzweig, Alternative Actionability in the Conflict of Lazus of Entcrprise Liability, 63 JURID. REv. 39 (1951).

5. For a list of statutes, see KunstLer, ACcidents 82 (1954). 
primary topic of this study, though related problems, most of which will be discussed incidentally, invite similar solutions. These latter problems include those raised by the family-car doctrine, the classic liability of the master for his servant, the liability for animals, other enterprise liabilities without fault. and such fast disappearing curiosities as the husband's liability for his wife': torts.

According to the Restatement of the Law of Conflict of Lazus, "each state has legislative jurisdiction ${ }^{6}$ to determine the legal effect of acts done or eventcaused within its territory." And, "except in the case of harm from poison, when a person sustains bodily harm, the place of wrong is the place where the harmful force takes effect upon the body."8 Under these formulae one would expect that vicarious liability would be determined by that law which hal "legislative jurisdiction to determine the legal effect" of the accident, namely" the law of the place "where the harmful force takes effect upon the buly:" Not necessarily so, say the Restaters: "In order that the law of the state uf wrong may apply to create liability against the absentee defendant, he must in some way have submitted to the law of that state."

Such a rule clearly presupposes a function of vicarious liability keyed to the defendant's action. It has long been recognized by both courts and writers, however, that this liability is one devised primarily for the victim's protection and that any test of authorization "should be measured objecticely" (so as t" correspond with the limits of the social policy behind imposing vicarious liability) and not in terms of the employer's wish to limit his own liability."10 Concerning the automobile owner's liability, there has thus become prevalent at least in domestic law a "willingness to disregard the owner's limitations on authority once the court is convinced that they pertain to the mere manner of operating a vehicle."11 The owner may therefore "be held where his borrower (though having consent to begin with) uses the car . . . in a forbidden place...."12 This postulate is in keeping with one of the oldest rationalizations of all vicarious liability according to which "I am liable" because "I set the whole thing in motion, and what my servant does being done for my benefi: and under my direction, I am responsible for the consequences of doing it."'s:

That these policies governing the domestic rules of vicarious liabilities as such are inconsistent with the "submission test" offered by the Restat"me"m!

6. See EmRenzweig, Conflict of Laws 8-9 (1959), for a criticism of the use of this phrase and concept.

7. Restatearent, Confict of Laws § 377, comment a (1934).

8. Id. at 455 .

9. Id. § 387, comment $a$. At the 1928 meeting of the American Law Institute thi question was "still doubtful." Restatearent, Confzict of Laws $\S 418$, illustration $a$, at 64 (Tent. Draft No. 4, 1928).

10. 2 HARPER \& JaAres, TORTS $\& 26.7$, at 1380 (1956).

11. 2 id. $\$ 26.16$, at 1425 .

12. Ibid. See also Smith, Frolic and Detoutr, 23 Coluar. L. Rev. 716, 726 (1923).

13. Duncan v. Findlater, 6 Cl. \& F. 894, 910, 7 Eng. Rep. 934, 940 (H.L. 1839). See also 2 HARPER \& JAMrES, TORTS $\$ 26.5$, at 1370-74 (1956). 
and leading texts for the solution of conflicts cases in this field, should, at the outset, put us on guard as to the accuracy of this test. The attempt will be made in this Article to show that the authorities which apparently underlie this test, though supported, if not created by, such outstanding judges as Brandeis and Learned Hand, may and must be discounted as the outgrowth of a brief conceptualist era, and that this entire field may and should, therefore, be considered as one of first impression. It will further be shown that, so considered, the submission test should be replaced by a test based on reasonable insurability - a standard which should govern enterprise liability in general.

\section{Doctrine}

In Scheer v. Rockne Motors Corp., ${ }^{14}$ the leading case on the subject, Julge Learned Hand made application in New York of the owner's liability law of Ontario, the state of the accident, contingent upon whether the defendant owner had authorized the operator to act for him in that state, on the grounds that in the absence of such authorization, Ontario law would have "to reach beyond its borders, for the only acts by which the defendant connected itself with . . . [the operator] were in New York."15 This reasoning, like the Restatement formula modeled on it, assumes that the defendant can only be made liable for an "act." Obviously, such a basis of liability could have been required by the law of New York or Ontario, but it may not be stated as a postulate a priori. Such a postulate would, in the absence of an "act" of authorization, exclude both application in Ontario of Ontario law even if that law called for such application to all Ontario plaintiffs or to all Ontario accidents, and application in New York of New York law even if that law called for stuch application to all New York defendants or to all foreign accidents. On the other hand, if there was authorization, the New York court might have to apply the Ontario statute to all Ontario accidents even though all parties were New York citizens and thus had clearly not relied on, or even expected, application of Ontario law.

Judge Hand sought support for his a priori reasoning in Mr. Justice Brandeis' opinion in Young v. Masci. ${ }^{16}$ Masci involved a New York statute which provided for liability of the owner of a motor vehicle for any harm "resulting from negligence in the operation of such motor vehicle . . . in the business of such owner ... , by any person legally using or operating the same with the permission ... of such owner."17 The Court upheld as constitutional the application of that statute in New Jersey to the claim of a New York resident for harm caused in New York by an automobile driven to New York with the New Jersey owner's permission granted in New Jersey. Today nobody would doubt the constitutional right of a New Jersey court to adopt

14. 68 F.2d 942 (2d Cir. 1934).

15. Id. at 943 .

16. 289 U.S. 253 (1933).

17. Id. at 256 . 
or reject a conflicts rule referring it to the law of the place of the accident and plaintiff's domicile. ${ }^{18}$ But 1933 was the time of the climax of the ideology of vested rights and legislative jurisdiction. ${ }^{10}$ Only thus may we explain how defendant could have hoped to succeed with his claim of an immunity acquired in New Jersey "by virtue of the contract of bailment made there," exclusion of "the power of New York to make the absent owner liable ...."."Only thus may we explain why the Court found it necessary to base applicability of the New York statute on the ground that, when the New Jersey owner "gave permission to drive his car to New York, he subjected himself tu the legal consequences imposed by that State upon ... negligent driving . . . . Whether we must consider this argument still valid is doubtful since the underlying concepts of vested rights and legislative jurisdiction have since been abandoned. ${ }^{23}$ But whatever be the answer to this question, the Silicr court recognized that it could not rely on the constitutional argument of Masci, since that case had not decided whether application of the law of the place of accident would, in the absence of "subjection," violate due process. ${ }^{24}$ Accordingly, Hand invoked the Masci case as having established a nonconstitutional rule of choice of law, although, contrary to the reasoning he employed, it was by no means "inevitable that the opinion [in Masci] should [be] read equally as one ... on the conflict of laws."25

Be this as it may, both Masci and Scheer have lost whatever standing they may have had as precedents, if for no other reason than that they announced a federal conflicts rule and such rules are no longer binding on either state or federal courts. ${ }^{26}$ To be sure, one later case decided by Judge Hand briefly. echoes the Scheer language. In Siegmam v. Meycr, ${ }^{27}$ decision was for the

18. See Ehrenzweig, Conflict of Laws 13-14 (1959), as to Mrr. Justice Brandeis' views expressed in other cases.

19. Id. at 8-9.

20. Young v. MFasci, 289 U.S. 253, 258 (1933).

21. Id. at 256 .

22. Ibid.

23. See Currie, The Constitution and the Choice of Law: Govennmental Intirists and the Judicial Furrction, 26 U. CHI. L. REv. 9, 71 n.283 (1958).

24. Authorization was recently held a constitutional requirement in an intrastate case. In Frankel v. Cone, 214 Ga. 733, 107 S.E.2d 819 (1959), 10 Mresces L. REv. 338, a Georgia owners' liability statute was held to violate due process since in the court's view it made an owner liable for the negligent conduct of another, even though a trespasser was uperating the vehicle against the express orders of the owner "irrespective of how carciul or free from negligence" the latter was. $214 \mathrm{Ga}$ at 736, 107 S.E.2d at 822 . See also the peculiar corrective interpretation of the Massachusetts statute which makes registration of an automobile prima facie evidence of responsibility on the part of the registered owner in Cardell v. Morrison, 138 F. Supp. 817 (D. Mass. 1956). But see 2 Happer \& Jasses, ToRrs $\S 26.16$, at 1424 (1956).

25. Scheer v. Rockne Motors Corp., 68 F.2d 942, 945 (2d Cir. 1934).

26. Klaxon Co. v. Stentor Elec. Mfg. Co., 313 U.S. 487 (1941); see Euresizweac, CONFLICT OF LAWS 29-30 (1959).

27. 100 F.2d 367 (2d Cir. 1938). A similar case is Hudson v. Von Hamm, 85 Cal. App. 323, 259 Pac. 374 (Dist. Ct. App. 1927) (parental liability under Havaii law unenforceable under the forum's public policy). 
New York defendant in a New York action for an assault allegedly conımitted by his wife in Florida where he would have been liable under the common-law rule abolished in New York. Judge Hand, citing Scheer in another context, argued that a relation of agency would be "determined by the law of the place where the acts take place which are relied upon to create it."28 But this argument seems clearly makeweight. Perhaps because the "agency" test would have subjected the husband to the fortuitous law of the state of the marriage, Judge Hand relied principally upon his local-law theory under which "it is impossible" for a court to enforce any liability except one created by the law of the court in which it sits," 29 and found that New York, although it might in general accept the pattern set by another state, would in this case "not recognize as a model for any liability which she will impose, a liability imposed by another state upon an absentee non-resident."30 "Gone is "submission" as a condition for applying the foreign statute. Gone is the foreign statute's "reaching beyond its borders." And gone is the authority of the Scheer case. For, tunder the local-law theory of the Siegmann case, the Scheer court, since its own statute was similar to that of the place of accident, would certainly have been justified in holding for the plaintiff on the "model" of the law of Ontario, regardless of authorization. ${ }^{31}$ Without the authority of Scheer and Masci, the Restatement and the judicial reasoning based on it remain without foundation. Since there is no indication that modern courts would give such reasoning more than verbal application, ${ }^{32}$ we are free to look for guidance in our search for the law to the actual holdings of these courts.

\section{The Law}

Once we have discounted those numerous cases in which conflicts rules were invoked though all pertinent laws were identical, or at least not asserted to be different, ${ }^{33}$ the vast majority of all remaining cases consists of those which,

28. 100 F.2d at 368.

29. Id. at 367 .

30. Id. at 368. For a more recent assault case, see Burgert v. Union Pac. R.R., 240 F.2d 207 (8th Cir. 1957). In that case, however, the pertinent laws do not seem to have differed as to the scope of vicarious liability.

31. On the local law theory, see generally Cavers, The Two "Local Law" Theorics, 63 Harv. L. Rev. 822 (1950) ; Morris, The Proper Law of Torts, 64 HARv. L. Rev. 881, 891 (1951).

32. Judge Hand relied on Scheer in Gratz v. Claughton, 187 F.2d 46 (2d (ir.), corl. denied, 341 U.S. 920 (1951). The Gratz case, however, involved an intentional tort rather than enterprise liability. See Ehrenzweig, The Place of Acting in Intentional M/ullistald Torts: Law and Reason Versus the Restatement, 36 Mins. L. REv. 1, 28 n.121 (1951).

33. In Cardell v. Morrison, 138 F. Supp. 817 (D. Mass. 1956), the court applied the lex fori to a Connecticut accident, its attention not having been called "to any law of Connecticut." Id. at 818. In Selles v. Smith, 4 N.Y.2d 412, 151 N.E.2d 838, 176 N.Y.S.2d 267 (1958), judgment for plaintiff was reversed because common-law agency required under the common law of New York had not been proved. The New York common law was presumed to be applicable in South Carolina whose law was not proved. (That the court declared the more liberal New York statute inapplicable was probably rendered 
in accordance with the principle prevailing in conflicts law in general, have in effect applied the lex for $i^{34}$ Courts have reached this result either by referring to the territorial scope of their own ${ }^{35}$ or foreign laws, ${ }^{30}$ or by simply resorting to their own public policy. ${ }^{37}$ Among the exceptions are thuse case: in which application of the lcx fori would not have been appropriate as the

harmless by dicta concerning the likely existence of agency. But the court's reasoning is misleading.)

Other cases in which no substantive conflict existed include Corban v. Skelly Oil Co., 256 F.2d 775 (5th. Cir. 1958) (independent contractor); Phillips v. Seltzer, 2tU 1.2d 857 (2d Cir. 1957) (lessor's liability); Kass v. Gilkerson, 199 F.2d 398 (D.C. Cir. 1952) : Haw v. Liberty Mut. Ins. Co., 180 F.2d 18 (D.C. Cir. 1950) ; Venuto v. Robinson, 118 F.2d 679, 682 (3d Cir.) (Goodrich, J.), ecrt. denicd, 314 U.S. 627 (1941) (independent contractor, lex fori and lex loci probably identical with other pertinent laws); Rubenstein v. Williams, 61 F.2d 575 (D.C. Cir. 1932); Herr v. Holohan, 131 F. Supp. 777 (D). Mld. 1955) (automobile owner); Fitzgerald v. Conklin Limestone Co., 131 F. Supp. 532, 335 (D.R.I. 1955) (independent contractor, "general rule") ; D'Aquilla v. Pryor, 122 F. Supp. 346 (S.D.N.Y. 1954) (airplane owner's nonliability stated to be identical under lex fori iuml lex loci); Molina v. Sovereign Camp, W.O.W., 6 F.R.D. 385, 395 (D. Xeb. 1447) (vicarious liability for fraud, Mexican law not pleaded); MIuraszki v. William L. Cliffurd, Inc., 129 Conn. 123, 26 A.2d 578 (1942); Laughlin v. Michigan Mfotor Frcight Lines, 270 Mich. 545, 268 N.W. 887 (1936); Nepstad v. Lambert, 235 Mfinn. 1, 50 N.W.2d olt (1951) (case of first impression under lex loci, in effect applied lex fori): American Carrier Corp. v. Avigliano, 123 N.J.L. 490, 9 A.2d 788 (Sup. Ct. 1939) (Iex fori) ; Traub v. Blum, 263 App. Div. 92, 31 N.Y.S.2d 735 (1941).

Unnecessary conficts have been created by an inconsistency in the Federal Turts Claims Act, 28 U.S.C. $\S \S 1346,1402,1504,2110,2401-02,2411-12,2671-80$ (1958), which in defining "scope of employment" in $\S 1346$, refers to "the law of the place where the act or omission occurred" (rather than the place of harm), and then, in $\$ 2671$, defines the same phrase when applied to military persomel as "acting in the line of duty." The courts are using federal and state authority interchangeably. See, e.g., Sample v. United Stater. 178 F. Supp. 259 (D. Minn. 1959). For the conflicts treatment of governmental liability abroad, see Schwimann, Internationale Zuständigkcit susd ansunuendendes Rccht in Amtshaftungssachen, 81 JURISTISCEE BLïTtER 585 (1959).

34. This includes those cases where the place of wrong was in the forum state. Ste, e.g., Hooten v. Civil Air Patrol, 161 F. Supp. 478 (E.D. Wis. 1958). For the thesis that application of the lex for $i$ is the prevailing principle, see authorities cited note 1 supra.

35. In Kernan v. Webb, 50 R.I. 394, 148 Atl. 186 (1929), a Rhode Island unners: liability statute was held applicable to a Rhode Island accident although the assumed prermission to use the car in that state had been given in Massachusetts, a state lacking a similar statute. The case therefore does not involve the question whether permission is required to "subject" the owner to the liability statute of another state, but is based on the lex fori et loci But see O'Connor v. Wray, [1930] Can. Sup. Ct. 231, [1930] 2 D.L.R. 899, discussed and approved in 2 Beale, Conflict of Laws 1296 (1935); Ditex, CONFLICT OF LAws 958 (7th ed. 1958).

36. In Zotvin v. Peoples Brewing Co., 225 Wis. 120, 273 N.W. 466 (1937), the owners' liability statute of Afinnesota, the defendant's state, was held inspplicable being in terms limited to intrastate accidents. This construction of the Minnesota statute was approved in Darian v. McGrath, 215 Minn. 389, 10 N.W.2d 403 (1943).

37. In Victor v. Sperry, 163 Cal. App. 2d 518, 329 P.2d 728 (Dist. Ct. App. 1958), the California court refused to apply a Mexican owners' liability rule to a Mexican accident between California citizens, though paradoxically accepting the Mfexican limitation oi 
forum state had no relevant contacts with the case. ${ }^{88}$ The few other cases in which courts have applied a law other than their own fail to offer the clue for the formulation of a satisfactory rationale.

For example, in Strogoff v. Motor Sales Co., ${ }^{30}$ defendant, Motor Sales Co., a Connecticut corporation, when lending an automobile to its office manager for use during his vacation, had violated a Connecticut registration statute. Suit was brought in Massachusetts by a Massachusetts resident for injuries sustained in a Massachusetts accident. Plaintiff attempted to invoke a Massichusetts statute under which anybody who had placed an automobile on the highways unlawfully was liable as a trespasser. Decision was for the defendant because he had done "nothing in Connecticut that would create a liability there" and had not known that his agent "intended to take" the automobile to Massichusetts. ${ }^{40}$ Both the result and the reasoning, ignoring plaintiff's right to protection under his own law, follow the obsolete thought underlying the Schicer case that owners' liability statutes are primarily concerned with the defendant's "act."

None but doctrinal, and possibly nonlegal, reasons appear in another case in which the court refused to apply its own law. A Pennsylvania minister, on the occasion of visiting his son in New York shortly after having recovered from an illness, gave permission to his son and the son's fiancee to use his car (then garaged in New York) for a trip to New Jersey. In an accident in the latter state the son was killed. His fiancee and her mother attempted to recover for the daughter's personal injuries by suing the Pennsylvania owner in New York under the New York owners' liability statute. The court dismissed the suit on the grounds that the New York statute had "no extraterritorial effect," 4 and no similar statute of New Jersey had been proved. But since Pennsylvania had a statute similar to New York's, defendant could hardly have claimed reliance on nonliability and no compelling reason existed to deny application of New York law. Only the special equities of the case can explain this decision; it should not serve as a precedent for a purely formalistic approacl.

damages as to another defendant. Wholesale application of the lex fori at the outset would have produced a more equitable result. See also Hudson v. Von Hamm, 85 Cal. App. 323, 259 Pac. 374 (Dist. Ct. App. 1927),

38. See Ehrenzweig, Conflict of Laws 1-2 (1959), on the problems created by the catch-as-catch-can rule of personal jurisdiction. In Rubin v. Schupp, 127 F.2d 625 (9th Cir. 1942), a Missouri plaintiff and an Oklahoma defendant had agreed in the California court on the applicability of the owners' liability statute of Missouri, the place of accident. Even without such agreement the parties should have been permitted to escape the lev fori which apparently lacked all contact with the case."

39. 302 Mass. 345, 18 N.E.2d 1016 (1939).

40. Id. at 345, 18 N.E.2d at 1017. But cf. Cardell v. Morrison, 138 F. Supp. 817, 819 (D. Mass. 1956), assuming that the Massachusetts courts would give "extraterritorial" application to a Massachusetts statute which made registered ownership prima facic evidence of responsibility.

41. Cherwien v. Geiter, 272 N.Y. 165, 5 N.E.2d 185 (1936). See also Miranda v. Lo Curto, 249 N.Y. 191, 163 N.E. 557 (1928); Comment, 21 Corsell L.Q. 303 (1936). 
We agree with the dissent in the lower court, which argued that "the law of the forum in respect ... of fundamental liability should be applied." 42 English law continues to support this conclusion. ${ }^{\mathbf{1 3}}$

The need for restoring the lex fori to its proper place is apparent not only in the Scheer, Masci, and Siegmann cases with their doubtful "authorization" theory or in cases such as the two just discussed in which dogmatic deviation has produced the wrong result, but also in those cases where courts were able to reach a desirable result by resorting to one or several of our conflicts curealls such as renvoi, public policy, or recharacterization. The last technique may be exemplified by reference to the much-praised and much-maligned case of Levy v. Daniels' U-Drive Auto Renting Co. ${ }^{\text {s }}$ In that case the Connecticut court held defendant renting agency liable under a Connecticut statute for harm caused by one of its customers to a passenger in Massachusetts. ${ }^{45}$ Could not the court have simply applied its own law in the absence of a compelling reason to the contrary? Could defendant seriously have been heard with the claim that plaintiff's right, if any, had to vest under the law of MIassachusetts, the fortuitous place of accident? Clearly the defendant could not rely on any expectation of the applicability of a more lenient law than that of Connecticut. And yet the court, beset by the doctrinal compulsions of its time, had to resort to a characterization of its problem as one of contract in order to invoke the law of Connecticut as that of the place of contracting.

This technique would compel denial of the claim of a Connecticut citizen brought in a Massachusetts court on a Connecticut accident against a Massachusetts renting agency because Massachusetts law had become part of the contract. In view of its fortuitous basis this result would be as unsatisfactory as the opposite one which would be reached under a delictual place of harm rule. To avoid it, the Massachusetts court would have to resort to a device chosen by the Levy court more than twenty years later when it confirmed applicability of the same Connecticut statute in a suit against Rhode Island citizens on a Massachusetts accident involving a truck registered in Rhode

42. Cherwien v. Geiter, 244 App. Div. 814, 815, 279 N.Y. Supp. 553, 554 (1935) (dissenting opinion) (contractual characterization). Concerning the owners' liability law of Pennsy:vania under which defendant had to expect and insure against such liability, see Herr v. Holohan, 131 F. Supp. 777 (D. Md. 1955).

43. See Liverpool, Braz. \& River Plate Steam Nav. Co. v. Benham, L.R. 2 P.C. 193 (1868) (The "Halley") (shipowner's liability for his pilot's negligence denied under the lex fori); accord, O’Connor v. Wray, [1930] Can. Sup. Ct. 231, [1930] 2 D.L.R. 899. But cf. The M. Moxham, 1 P.D. 107 (C.A. 1876), recersing 1 P.D. 43 (1875) (Iex loci applicable as defense to lex fori liability). See generally Dicey, Coxfuct of LAws 958 (7th ed. 1958).

44. 108 Conn. 333, 143 Ati. 163 (1928). For criticism of this case on dogmatic grounds, see, e.g., Hanseman v. Hamilton, 176 F. Supp. 371 (D. Colo. 1959); Goonruca, Cosifuct of Laws 279-80 (3d ed. 1949). But cf. the excellent analysis in Stuarberg, Cosirust of Laws 204-05 (2d ed. 1951) ; Morris, The Proper Law of Tort, 64 Hanv. L. REv. 880, 889 (1951). (1959).

45. On this type of legislation, see generally Comment, 2 Was. \& MARY L. REv. 284 
Island and garaged in Connecticut. The court conceded that the rental agreement might have been entered into in Pennsylvania, but held the contract subject to the law where it was "to be performed or to have its beneficial operation ...."46 This law was that of Connecticut because "the truck could not be operated in either Massachusetts or New York until it had covered, in Connecticut, the distance from the place where it was kept to the state line." 17 Reference to the nondisplaced law of the forum would have been easier. In ascertaining the existence and scope of exceptions from the applicability of that law in this field, we shall have to disregard judicial language and try to formulate the true rationale of the available decisions.

\section{Rationale}

The following rationalization of the Levy case, it is submitted, woukd produce a generally acceptable solution: The Connecticut agency, in calculating its rates and planning its insurance, certainly had taken into account the law of Connecticut. Connecticut, presumably, considers its law the basis for a fair distribution of statistically inevitable accident losses. ${ }^{48}$ This law was, therefore, the law properly applicable to any accident caused by one of the agency's cars kept, rented, and insured in Connecticut ; and any more lenient laws prevailing elsewhere could not benefit the defendant. Wherever injured or resident, the plaintiff in the Connecticut court can rely on the lex fori which will not admit of any exceptions.

The problem is more complex in the case of an agency operating under a law lacking an owners' liability statute of the Levy type. Such an agency will in the first place calculate and insure its losses in the light of its own law which will generally limit its liability to losses caused by its negligent employees within the scope of their employment. ${ }^{40}$ And potential traffic victims resident in this state, when planning their insurance programs (or, more realistically, their accident insurers when calculating their premiums), should, and ultimately will, take into account the additional risk of being injured by financially irresponsible renters (or, more realistically again, with regard to the family-car doctrine, by financially irresponsible teenagers). But the agency cannot always rely on its own lenient law. In one case the impact of stricter foreign laws is clearly unavoidable. Where the agency consents to its car being taken to Connecticut, a jurisdiction with an owners' liability law, immunity to the law

46. Graham v. Wilkins, 145 Conn. 34, 40, 138 A.2d 705, 708 (1958).

47. Ibid.

48. Admittedly the court in the Levy case preferred to rationalize application of the lex for $i$ as that of a law primarily designed "to protect the safety of the traffic upon highways by providing an incentive to him who rented motor vehicles to rent them to competent and careful operators...." 108 Conn. at 336, 143 Atl. at 164 . But this somewhat unrealistic rationale was apparently chosen to avoid the place-of-harm rule. Once it is recognized that the injured person's right is not tied to this rule, but follows the principle of reasonable insurability, the admonitory reasoning in the Levy case becomes dispensable.

49. Concerning the family purpose doctrine exception and Florida practice, sec Prosser, Torts 369-71 (2d ed. 1955). 
of the latter state would adversely affect the position of potential victims and their insurers concerning accidents there. In a Connecticut suit there is little doubt that the agency will not be permitted to escape application of the basic law of the forum by claiming its Massachusetts contract under the theory of the Levy case. But forum law as such should not determine the liability. Defendant's reliance both on the law of the forum and on the law of contracting must fail when suit on the Connecticut accident is brought in Massachusetts. In all probability, plaintiff will have been forced into the MIassachusetts court by an unsatisfactory law of jurisdiction. He cannot be expected to have insured against application of the unfavorable law. On the other hand, the Massachusetts agency, when permitting its vehicle to be used in Connecticut, could and should have foreseen and insured against liability under Connecticut law to any user of the Connecticut highways properly relying on the protection of the laws of that state. And this reliance seems as justified for a transient as for a citizen of the state of the accident.

The only doubtful case could be that of the borrower who drives the car to an owners' liability state without the owner's consent. In nonconflicts cases growing concern for the victim has extended the master's liability generally to include many situations in which the servant has exceeded the scope of his employment. Such excesses of authority are in effect charged to the master in most cases in which they are somehow typical for the enterprise and thus foreseeable and insurable, as in the case of deviations concerning the "mere manner of operating." 50 It seems only consistent to treat entering another state as such a manner of operating, and to hold both master and owner, without regard to their consent, under any "foreseeable and insurable law." Indeed, few would believe that, in the Scheer situation, an Ontario court would have hesitated to apply its own law to the Ontario accident in protecting an Ontario citizen, merely because the New York owner had not "submitted" to that law. Clearly the lex fori would have prevailed. Similarly, few would believe that in the Levy situation, the Connecticut court would have denied the Massachusetts plaintiff's claim merely because the contract had prohibited use of the rented car in Massachusetts. And the Massachusetts court should certainly have applied its own law in the Motor Sales case, notwithstanding the Connecticut owner's restrictions on the use of the car. ${ }^{\text {.1 }}$

50. 2 HARPER \& JANres, TORTS $\$ 26.16$, at 1425 (1956). On this theory the dumicile test suggested by some continental courts and writers is not acceptable. While this test will protect the owner or master from unexpected liabilities, see, e.g., 2 Zirelssais:s, Internationales Prtvatrecht 532-44 (1912), it goes too far in extending this protcetion to harm foreseeably and avoidably occurring elsewhere without the owner's or master's consent. See generally 2 Raber, Conflict of Laws $268-76$ (1947); LoRenzes; Seuscted Articles on the Conflict of Laws 374 (1947).

51. Plaintiff, when using the highways of Mfassachusetts, was entitled to expeet the protection of the laws of that state, and defendant could easily have protected itself against liabilities under these laws by preventing the automobile from leaving the state, or by insuring itself against the consequences of use outside. Defendant had no ground on which he could object to the application of the lex fori, the basic law of tort conflicts. 
"Insurable laws" include at least the law of the defendant's domicile (or, in automobile cases, the state where his car is permanently kept), the law of the place of accident, and probably the law of the plaintiff's residence in this or a contiguous country. Among these laws, then, even in the absence of the lender's consent, the plaintiff should be able to choose by choosing his forum. But limits on the application of the lex fori are necessary to exclucle undesirable forum shopping. A Massachusetts plaintiff injured in his own state by a car rented in a state equally lacking an owners' liability law, should not be able to avail himself of the owners' liability law of Connecticut by bringing suit in that state after acquiring a mere transient jurisdiction over the defendant. Perhaps this limitation will some day be achieved by a more rational law of jurisdiction -now in the making - which would exclude transient jurisdiction. ${ }^{\text {t2 }}$ Until then, the defendant must be permitted to prove that Connecticut law was not one whose impact on its operations could reasonably have been foreseen and insured against-i.e., that its application to this particular case would be purely fortuitous. On the other hand, under our present law of juriscliction, plaintiff will occasionally have to be given the right to invoke a law other than that of the forum. In all probability the Connecticut victim of a Massachusetts acciclent caused by a car rented from a Massachusetts agency would, in a Connecticut court, be permitted to rely on Connecticut law. He should not be deprived of this choice by being unable to obtain jurisdiction over the defendant in Connecticut and must, in a Massachusetts court, be permitted to rely on Connecticut law as one reasonably foreseeable and insurable by the defendant.

On this theory, the Scheer case would have been decided for the plaintiff. Judge Goodrich has urged this result on ather grounds :

If a man sets off a blast of dynamite, ${ }^{53}$ or keeps a dog, ${ }^{54}$ either of which does harm to the plaintiff in another state, ... . the second state's rule is applied to fix the actor's liability. May not the same rule be applied

52. See Ehrenzweig, Conflict of Laws 102-06 (1959); Ehrenzweig, The Transicm Rule of Personal Jurisdiction: The "Power" Myth and Forum Conveniens, 65 Y ALE L.J. 289 (1956).

53. The dynamite cases do not establish a clear conflicts rule. See Dallas v. Whitney, 118 W. Va. 106, 188 S.E. 766 (1936). The law of West Virginia was later found to be the same as that of Ohio. Britton v. Harrison Const. Co., 87 F. Supp. 405 (S.D.W. Va. 1948). In Cameron v. Vandergriff, 53 Ark. 381, 13 S.W. 1092 (1890), damages werc allowed under Arkansas law for harm caused by a blasting operation in Indian territory. But the rules of ordinary negligence applied in this case were probably the same under both pertinent laws. Related railroad spark cases are similarly inconclusive. See Connceticut Valley Lumber Co. v. Maine Cent. R.R., 78 N.H. 553, 103 Att. 263 (1918); Otey v. Midland Valley R.R., 108 Kan. 755, 197 Pac. 203 (1921); Ehrenzweig, The Place of Acting in Intentional Multistate Torts: Law and Reason Versus the Restatement, 36 Mins. L. Rev. 1, 17 (1951); Rheinstein, The Place of Wrong: A Study in the Mcthod of Case Lazv, 19 Tuz. L. Rev. 165, 167-68 (1944). See generally Annot., 20 A.L.R.2d 1372 (1951).

54. In Fischl v. Chubb, 30 Pa. D. \& C. 40 (C.P. 1937), a New Jersey strict-liability statute was applied to the bite in that state of a Pennsylvania dog by simple reference to the place of harm rule. When the court in Le Forest v. Tolman, 117 Mass. 109 (1875), 
when the harm comes from the defendant's car and a person to whom the car is entrusted? The owner has not voluntarily submitted his car to the operation of the second state's law, but he has voluntarily parted with it, and it might well be held that the risk of both disobedience of orders and negligence by the bailee should be on the lender. ${ }^{55}$

A Florida court has so held with regard to its unique common-law Dangerous Instrumentality doctrine. ${ }^{56}$ Defendant Georgia company objected to a jurisdiction claimed on the basis of a nonresident motorist statute in an owners' liability suit under Florida law inter alia on the ground that it had not consented to the use of the rented vehicle in Florida. Jurisdiction was upheld ${ }^{\text {it }}$ in the light of a decision of the Florida Supreme Court which stated in part:

When this defendant turns over an automobile to another for a price, he in actuality entrusts that automobile to the renter for all ordinary purposes for which an automobile is rented. The fact that the owner had a private contract or secret agreement with the renter cannot make such restrictions a bar to the rights of the public. The restrictions agreed upon do not change the fact that the automobile was being used with the owner's consent. ...58

These conclusions cannot remain limited to the lender who has "voluntarily parted" with the car "for a price." The gratuitous lender, like all motorists, is also a member of the community of risk. ${ }^{59}$ Nor is there a reason for not ultimately extending liability to the car owner as such to cover harm caused by his car in the hands of a thief under the law of any state recognizing such liability, in the same manner as the owner of a dog is thus liable without having voluntarily parted with him. All that is needed is that the application of the law imposing such liability be foreseeable and calculable by the defendant. ${ }^{60}$

refused to apply a similar forum statute in a case involving a Massachusctts dog biting in New Hampshire, it had not yet been affected by the Restatement doctrine and had to find refuge in the fact that "the act of the dog" had been committed in New Hampshire. Should not the true rationale have been the absence of liability insurance which was available in the Fischl case? See Ehrenzweig, The Place of Acting in Intentional MIultistate Torts: Laz' and Reason versus the Restatment, 36 Mfrs. L. Rev. 1, 24-25 (1951). For a dog case with a gratuitous discussion of conflicts rules, see Thompson v. Wold, 47 Wash. 2d 782, 289 P.2d 712 (1955). See generally Comment, 1960 DukE L.J. 146.

55. Goodrice, Confuict of Laws 279 (3d ed. 1949) (the footnotes are mine, not Judge Goodrich's) ; accord, 2 RABEL, CoNflict of LAws 272 (1947).

56. The doctrine is stated in Southern Cotton Oil Co. v. Anderson, $80 \mathrm{Fla} .41,86$ So. 620 (1920). See also 2 HARPER \& J AMrEs, TORTS $\$ 26.10$, at 1394 n.9 (1956).

57. Bowman v. Atlanta Baggage \& Cab Co., 173 F. Supp. 282 (N.D. Fla. 1959).

58. Leonard v. Susco Car Rental Sys., Inc, 103 So. 2d 243, 247 (Fls. Dist. Ct. App. 1958), aff'd, 112 So. 2d 832 (Fla. 1959).

59. Young v. Masci, 289 U.S. 253, 258 (1933), seems to cover this case. "A person who sets in motion in one state the means by which injury is inflicted in another may... be made liable for that injury whether the means employed be a responsible agent or an irresponsible instrument." For criticism, see 2 BeAlE, CoNfluct of LAws § 383.1 (1935) ; cf. 2 RaBEI, CONFLICT of LAws 269-70 (1947).

60. For railroad and bus operations, calculations (and self-insurance) can casily be, and are properly, keyed to the laws governing trackage and routing. See, c.g., South- 
Only in rare cases would this condition fail, as for example if a stolen car or dog caused harm in a faraway country.

The same principles will help in solving such problems as might still arise under the multiform antiquated law of master and servant. The fellow-servant rule was hardly defensible when it was introduced in this country. ${ }^{01}$ Today it should not seriously be contended that, as the Restatement of Conflicts would have it, ${ }^{62}$ an employee could, under this rule, be deprived of a right to recovery which he would have under the law of his own state, merely because the rule has been preserved at a fortuitous place of accident. In fact, none of the pertinent cases has ever so held although the lex loci has occasionally been applied to permit recovery. ${ }^{63}$ Liability under the law of the employee's residence is certainly reasonably foreseeable and insurable by the employer. ${ }^{04}$ This

western Greyhound Lines v. Crown Coach Co., 178 F.2d 628 (8th Cir. 1949) (contribution statute) ; Price v. Atchison, T. \& S.F. Ry., 164 Cal. App. $2 d$ 400, 330 P.2d 933 (Dist. Ct. App. 1958) (res ipsa loquitur) ; Stefan v. Elgin, J. \& E. Ry., 16 Ill. App. $2 d 468,148$ N.E.2d 606 (1958) (last clear chance); O'Leary v. Illinois Terminal R.R., 299 S.W.2d 873 (Mo. 1957) (burden of proof) ; Jones v. Illinois Terminal R.R., 272 S.W.2d 272 (Mo. 1954) (humanitarian doctrine, last clear chance). But see Hollinquest v. Kansas City So. Ry., 88 F. Supp. 905 (W.D. La. 1950), applying a strict-liability statute of the forum to : foreign accident by virtue of a ticket purchased in the forum state. On the other hand, air carriers whose accidents cannot with certainty be expected to occur in specific territories, should not be permitted to invoke a more lenient law of the fortuitous place of accident. Hospitals necessarily operate and insure under the law of their location.

For cases relying unnecessarily on conflicts rules in the absence of conflicts, sce, c.g., Watn v. Pennsylvania R.R., 255 F.2d 854 (3d Cir. 1958) ; Bullock v. Pennsylvania Greyhound Lines, 261 F.2d 375 (D.C. Cir. 1958) ; Miller v. Pennsylvania R.R., 251 F.2d 376 (D.C. Cir. 1957) ; Hall v. United States, 136 F. Supp. 187 (W.D. La. 1955) ; Brown v. Pennsylvania Greyhound Lines, decided sub nom. Rhodes v. Barnett, 117 F. Supp. 312, 317 (S.D.N.Y. 1953).

For a case deliberately refraining from deciding an unnecessary conflicts question, see Johnson v. Eastern Air Lines, 177 F.2d 713 (2d Cir. 1949).

61. See Prosser, Torts 380-82 (2d ed. 1955).

62. Restatement, Conflict of Laws $\$ 386$ (1934).

63. In El Paso \& N.W.R.R. v. Comas, 36 Tex. Civ. App. 170, 81 S.W. 760 (1904) (lex loci identical with lex fori); Rick v. Saginaw Bay Towing Co., 132 Mich. 237, 93 N.W. 632 (1903); and Anderson v. Milwaukee \& St. P.R.R., 37 Wis. 321 (1875), plaintiff recovered under the lex loci. The only support for the Restatement rule as to denial of recovery seems to be a dictum in De Harn v. Mexican Nat'l Ry., 86 Tex. 68, 23 S.W. 381 (1893). In Baruch v. Sapp, 178 F.2d 382 (4th Cir. 1949), plaintiff was denied recovery by the South Carolina court against a South Carolina resident under the Kansas fellowservant rule. But not only was plaintiff's decedent a Kansas resident, but South Carolina law was probably the same as Kansas law. See S.C. Const. art. 9, \& 15. Moreover, the court had found "a grave question" whether defendant was not entitled to a directed verdict because of decedent's misconduct. 178 F.2d at 386. Alabama Great So. R.R. v. Carroll, 97 Ala. 126, 11 So. 803 (1892), denying recovery to an Alabama brakeman against an Alabama corporation for injuries sustained in Mississippi, under the Mississippi fellowservant rule, though an Alabama statute would have permitted recovery, was based in part on a construction of that statute, and can probably be discounted as the product of early judicial antilegislative attitudes.

64. This test, rather than the place-of-wrong rule should also be applicable to the scope of employment within which the master is liable. But see Restatentent, Confuict 
conflicts theory of reasonable insurability is, as has been shown in the two previous studies, in accord with that suggested for other kinds of enterprise liability. ${ }^{65}$

The test urged for the scope of enterprise liability in general becomes applicable to its territorial scope:

We are ... looking . . . for risks that may fairly be regarded as typical of or broadly incidental to the enterprise he has undertaken .... [O] ne of the purposes for such a quest is to mark out in a broad way the extent of tort liability (as a cost item) that it is fair and expedient to require people to expect when they engage in such an enterprise, so there can be some reasonable basis for calculating this cost. ${ }^{.0}$

"Viewed in this perspective, the master should seldom indeed be exonerated when his affairs are being furthered by the use of an unauthorized vehicle."67 Here, as all through the law of vicarious liability, the "authority" test must fail as based on a fiction prompted by an archaic insistence on some "act" or even fault on the defendant's part to justify his liability. ${ }^{\text {es }}$ Once this anachronism is discarded, the lex fori supplemented by a test of reasonable insurability emerges as the rationally applicable law.

of LAws $\S 387$, comment $b$ (1934), and to the definition of an independent contractor exempted from this liability, id. $\$ 387$, comment $c$. Laughlin v. Mrichigan Motor Freight Lines, 276 Mich. 545, 268 N.IW. 887 (1936), the only case cited in support of the Restatement rule on the first proposition in Gooprich, CoNfurct of LAws $\$ 98$, at 278 (3d ed. 1949), is not in point, and involved questions as to which the pertinent laws did not differ. See also Corban v. Skelly Oil Co., 256 F.2d 775 (5th Cir. 1958) ; Venuto v. Robinson, 118 F.2d 679 (3d Cir.), cert. denied, 314 U.S. 627 (1941); Fitzgerald v. Conklin Limestone Co., 131 F. Supp. 532 (D.R.I. 1955).

65. See Ehrenzweig, Guest Statutes in the Confict of Laus-Toutard A Theory of Enterprise Liability Under "Foreseeable and Inuruble Laus": I, 69 Y ALE L.J. 595 (1960); Ehrenzweig, Products Liability in the Confict of Lawes-Toutard a Theory of Enterprise Liability Under "Foreseeable and Insurable Lan's": II, 69 YALE L.J. 794 (1960).

66. 2 HARPER \& JAMres, TORTS $\$ 26.7$, at 1376 (1956), approving the typieality test suggested in EHrenzweig, Negligence Without Fault 52-54, 58-61 (1951).

67. 2 Harper \& JaMres, TORTS $\S 26.7$, at 1378 (1956).

68. See 2 id. $\$ 26.7$, at 1379, 1384; 2 RABEL, CONFLICT of LAws 271-75 (1947). See generally Ehrenzweig, $A$ Psychoanalysis of Negligence, 47 Nw. U.L. REv. 855 (1953). 


\section{THE YALE LAW JOURNAL}

\begin{tabular}{l} 
Volume 69 \\
\hline \\
JAMES M. EDWARDS \\
StEPHEN MANN \\
DoNaLd G. MARSHALL \\
RoBert L. WeINBERG \\
Note \& Comment \\
Editors
\end{tabular}

MAY 1960 NUMBER 6

Alan Appelbaums

Editor-in-Chief

DAVID ALbENDA

Neale M. Albert

Hershet Y. Allerhand

SteVEN D. ANDERMAN

HURd BARUCH

ARTHur J. BERK

Thonras B. BrackeN

Carroll W. Brewster

George B. Driesen

Benjamin S. DuVal, Jk.

EIIfEzer ERELI

David R. Evans

David I. Goldblatt
Harrison J. Goldin

Stuart B. Golparan

Lawrence G. Goodman

William S. Greenawalt

Richard S. Harrison

BENJAMIN T. HOPKINS, II

Robert E. Hudec

ROBERT A. JOHNSON

Arow Katz

LaWrence P. KLAMON

ZANE KLEIN

AlaN H. Molod

Bruce Montgomery

SAMuez Myers
James McC. Johnstone

Gilbert Paul Verbit

Article \& Book

Review Editors

EUGENE I. LAMBERT

Managing $\mathcal{E}$ Case

Editor

\author{
J. AleXANDER ONDERDONK \\ ALAN D. PEKELNER \\ Stoddard D. Platt \\ David A. Rosen \\ Herbert Schireiber \\ Richard Lauder Sutton \\ PETER R. TAFT \\ David M. Trudek \\ ADAM WALINSKY \\ Herdert S. WANder \\ DoNAld P. WeFER \\ SidNEY M. WOLINSKY \\ JERE A. YoUNG
}

\section{Marie McMahon \\ Business Secretary}

\section{CONTRIBUTORS TO THIS ISSUE}

Lours J. Hector. B.A. 1938, Williams College; 1938-1939, Oxford University ; LL.B. 1942, Yale University. Member of the Florida and District of Columbia Bars. Member, Civil Aeronautics Board, 1957-1959. Member of the firm of Hector, Faircloth \& Rutledge, Miami, Fla.

EARL W. Kintner. A.B. 1936, De Pauw University; J.D. 1938, University of Indiana. Member of the Indiana and District of Columbia Bars. Chairman, Section on Administrative Law, American Bar Association. Chairman, Federal Trade Commission.

Albert A. Ehrenzwetg. Dr. Jur. 1928, University of Vienna; J.D. 1941, University of Chicago; LL.M. 1942, J.S.D. 1952, Columbia University. Member of the New York Bar. Walter Perry Johnson Professor of Law, University of California, Berkeley.

Philip D. Weiss. A.B. 1955, Lafayette College. Third-year student, Yale Liw School. 